\title{
Partidarismo no Brasil: Análise longitudinal dos condicionantes da identificação partidária (2002-2014)
}

\author{
Partisanship in Brazil: longitudinal analysis of conditionants of \\ partisan identification (2002-2014)
}

\author{
Éder Rodrigo Gimenes \\ Wesley Oliveira Furriel \\ Julian Borba \\ Ednaldo Aparecido Ribeiro
}

\section{Resumo}

A relação entre eleitores e partidos tem sido tema recorrente em diversos trabalhos dentro das Ciências Sociais, principalmente no campo da Ciência Política. No caso brasileiro, uma análise longitudinal, desde a década passada, aponta expressivas oscilaçóes no percentual de eleitores identificados com partidos. Diante desse contexto, nosso objetivo foi identificar as mudanças no perfil sócio-econômico e atitudinal dos eleitores partidários entre 2002 e 2014, além de realizar uma breve comparação entre PT, PSBD, PMDB, PV e PSB. Para tanto, utilizamos, principalmente, dados coletados pelo Estudo Eleitoral Brasileiro (ESEB) de 2002, 2006, 2010 e 2014. Nossas conclusões mais relevantes são de que o eleitor partidário brasileiro é mais mobilizado cognitivamente em termos atitudinais, se comparado ao eleitor não partidário; porém, não há grandes distinçóes entre eleitores que se identificam com os partidos em destaque nas disputas presidenciais.

\section{Palavras-chave}

Identificação Partidária; Brasil; Partidos Políticos.

\begin{abstract}
The relationship between voters and parties has been a recurring theme in many works in the social sciences, especially in the field of Political Science. In the Brazilian case, a longitudinal analysis over the past decade shows a significant fluctuation in the percentage of voters identified with parties. In this context, our goal was to identify the changes in the socio-economic and attitudinal profile of party voters between 2002 and 2014, and create a brief comparison between PT, PSBD, PMDB, PV and PSB. For this study, we used data collected by the Estudo Eleitoral Brasileiro (ESEB) 2002, 2006, 2010 and 2014. Our main findings are that the Brazilian party voter is more cognitively mobilized in attitudinal terms, compared to non-partisan voter, but there are no major distinctions between voters who identify with the parties highlighted in presidential contests.
\end{abstract}

\section{Keywords}

Partisan Identification; Brazil; Political Parties. 


\section{Considerações iniciais}

A relação entre eleitores e partidos tem sido tema recorrente na agenda de pesquisas da Ciência Política. Um recurso frequentemente empregado para avaliar a natureza e intensidade dessa relação é o indicador de identificação partidária (IP), que também pode ser entendido como uma medida do grau de institucionalizaçáo do sistema partidário (DALTON, MCALLISTE e WATTENBERG, 2003; DALTON, 2013).

Parte da literatura especializada aponta para uma constante queda nos índices de identificação partidária e, consequentemente, para as limitaçóes desta medida principalmente enquanto variável explicativa do comportamento eleitoral. Como apontam Dalton, McAllister e Wattenberg (2003), decréscimos nessa medida foram constatados a partir da década de 1970 e, convergindo com o crescimento de tendências antipartidárias, levantaram dúvidas quanto ao seu valor explicativo.

No caso brasileiro, se considerarmos o período recente pós-redemocratização até as últimas eleiçôes presidenciais, não é possível constatar grandes alteraçôes nessa identificação. No entanto, cabe destacar uma forte oscilação negativa no meio da década passada, à qual muitos autores relacionam com escândalos e denúncias de corrupção, que atingiram várias legendas. Nos anos seguintes, verificou-se a retomada do percentual de indivíduos identificados com tais instituiçóes, ainda que em proporçóes diferentes das anteriores, quando analisados partido a partido. $\mathrm{O}$ destaque maior cabe ao PT, legenda responsável pelo Governo Federal no período e a mais atingida por denúncias; porém, também aquela que se recuperou de maneira mais efetiva da baixa generalizada da IP em 2005. Ademais, desde 2014, o cenário político é permeado por manifestaçóes de rua que, especialmente nos últimos dois anos, assumiram caráter extremamente crítico a políticos e partidos.

Diante desse contexto, o objetivo da investigação foi identificar as mudanças no perfil sócio-econômico dos eleitores partidários brasileiros entre os anos de $2002 \mathrm{e}$ 2014, além de realizar uma breve comparação entre os partidos que mais se destacaram nas disputas eleitorais presidenciais no período. Também procuramos verificar os efeitos sobre a identificaçáo partidária no que diz respeito a algumas dimensóes atitudinais e cognitivas dos eleitores, com o intuito de testar hipóteses derivadas das formulaçóes sobre mobilização cognitiva de Dalton (2013), bem como verificar a existência de diferenças entre os partidários do Partido dos Trabalhadores (PT), do Partido do Movimento Democrático Brasileiro (PMDB), do Partido da Social Democracia Brasileira (PSDB), do Partido Verde (PV) e do Partido Socialista Brasileiro (PSB), conforme a relevância de cada legenda nos pleitos majoritários. 
No período de 2002 a 2014, os partidos que tiveram maior expressão e também maiores índices de identificação partidária foram: PT, PSDB e PMDB. Ainda que as disputas presidenciais estejam polarizadas entre os dois primeiros partidos desde 1994 (BRAGA, 2010; MAYER, 2011), Sandes-Freitas (2013) e Couto, Abrucio e Teixeira (2013) destacam a relevância do PMDB no âmbito municipal e sua capilaridade em termos de implantação no território nacional. Entretanto, em se tratando de IP, Carreirão e Kinzo (2004), Veiga (2011) e Samuels e Zucco Junior (2012) verificaram, em suas análises, redução acentuada no percentual de identificados com tal partido, enquanto PT e PSDB apresentaram crescimento. É importante lembrar que o PV e o PSB se destacaram somente em 2010 e 2014, respectivamente, quando do lançamento de candidaturas próprias à presidência da República, as quais atingiram percentuais expressivos de votaçôes nos primeiros turnos das eleiçóes, conforme exposto na Tabela 1.

Tabela 1 - Resultados dos primeiros turnos de eleiçôes presidenciais no Brasil (1994-2014)

\begin{tabular}{l|c|c|c|c|c|c}
\hline & $\mathbf{1 9 9 4}$ & $\mathbf{1 9 9 8}$ & $\mathbf{2 0 0 2}$ & $\mathbf{2 0 0 6}$ & $\mathbf{2 0 1 0}$ & $\mathbf{2 0 1 4}$ \\
\hline Candidatos do PSDB $^{\mathrm{a}}$ & $\mathbf{5 4 , 2 8}$ & $\mathbf{5 3 , 0 6}$ & 23,19 & 41,64 & 32,61 & 33,57 \\
\hline Candidatos do PT $^{\mathrm{b}}$ & 27,04 & 31,71 & $\mathbf{4 6 , 4 4}$ & $\mathbf{4 8 , 6 1}$ & $\mathbf{4 6 , 9 1}$ & $\mathbf{4 1 , 5 8}$ \\
\hline $3^{\mathrm{o}}$ colocado $^{\mathrm{c}}$ & 7,38 & 10,97 & 17,86 & 6,85 & 19,33 & 21,31 \\
\hline Outros candidatos $^{2}$ & 11,3 & 4,26 & 12,51 & 2,9 & 1,15 & 3,54 \\
\hline
\end{tabular}

a 1994 e 1998 = Fernando Henrique Cardoso; 2002 = José Serra; 2006 e 2010 = Geraldo Alckmin; 2014 = Aécio Neves.

b 1994, 1998, 2002 e 2006 = Luiz Inácio Lula da Silva; 2010 e 2014 = Dilma Rousseff.

c 1994 = Enéas Carneiro (Partido da Reedificação da Ordem Nacional - PRONA); 1998 = Ciro Gomes (Partido Popular Socialista - PPS); 2002 = Anthony Garotinho (Partido Socialista Brasileiro - PSB); 2006 = Heloísa Helena (Partido Socialismo e Liberdade PSOL); 2010 = Marina Silva (Partido Verde - PV); 2014 = Marina Silva (PSB).

Fonte: Gimenes (2015, p. 184), baseado em dados do Tribunal Superior Eleitoral (TSE).

Destaque-se que a candidatura que ocupou a terceira posição nos pleitos mais recentes foi de Marina Silva, em 2010, pelo PV e, em 2014, pelo PSB. Considerada a hipótese de que os eleitores identificados com o PV em 2010 fossem simpatizantes da candidata e não do partido, optamos por mantê-lo na análise para 2014, a fim de verificar como se comportam os perfis dos eleitores que se identificam com os partidos pelos quais Marina Silva concorreu nos diferentes pleitos.

O estudo aqui apresentado utilizou, principalmente, os dados coletados pelo Estudo Eleitoral Brasileiro (ESEB) de 2002, 2006, 2010 e 2014. A intenção foi a de 
124 | Éder Gimenes, Wesley Furriel, Julian Borba e Ednaldo Ribeiro

desenvolver uma reflexão sobre as manifestações partidárias nas eleições presidenciais desde a última década, de modo a contribuir para o entendimento da identificação partidária no sistema democrático nacional.

\section{Perspectivas sobre a identificação partidária}

A queda nas taxas de identificaçáo partidária tem preocupado diversos cientistas políticos, sobretudo em razão dos seus efeitos sobre o desenvolvimento democrático. Nos Estados Unidos, inicialmente, o declínio do partidarismo foi associado a crises políticas exclusivas do país, a saber: os conflitos dos direitos civis, a guerra do Vietnã e a agitação urbana gerada por este momento (DALTON, 2013). Todavia, processos semelhantes de dealignment ${ }^{l}$ partidário também foram constatados em outras democracias, fato que exige uma reflexão mais cuidadosa e generalizável quanto a este fenômeno. A fragilidade da ligação entre cidadãos e partidos tem também se refletido em cenários de alta volatilidade eleitoral, caracterizados pela baixa lealdade dos eleitores em relação a legendas a cada eleição (DALTON, MCALLISTER e WATTENBERG, 2003; DALTON, 2013).

Outro indicativo do desgaste nessa relação é o crescimento do número de eleitores não partidários pós-década de 1970. No período de 1952 a 1964, aproximadamente $75 \%$ dos norte-americanos se declaravam Democratas ou Republicanos, ao passo que, após este período, os valores se inverteram, e a maior parte dos eleitores passou a se declarar independente dos partidos (DALTON, 2013).

Diante do cenário de volatilidade e queda das taxas de IP, do aumento dos eleitores independentes e da onda de sentimentos antipartidários, as pesquisas passaram a destacar certa preocupação quanto à crise dessas instituiçóes e, principalmente, quanto aos seus impactos sobre o desenvolvimento democrático, tendo em vista que os partidos sáo instituiçôes fundamentais para o funcionamento dessa forma de governo.

Alguns autores preocupados com esse tema têm analisado o vínculo partidário a partir do processo de socialização do indivíduo. Seguindo esta perspectiva, o indivíduo conviveria com seus pais, parentes ou amigos que são engajados ou demonstram simpatia por algum partido, e essas experiências socializadoras influenciariam a formação de suas preferências políticas (DALTON, 2013). Esta abordagem se aproxima da proposta pela Escola de Michigan, na qual a afeição

\footnotetext{
${ }^{1}$ Desalinhamento: período durante o qual a parcela do eleitorado de filiados em partidos sofre retração.
} 
partidária é interpretada como adesão psicossociológica, sendo forjada por bases afetivas durante o processo de socialização (FIGUEIREDO, 1991).

Por outro lado, os seguidores da abordagem da escolha racional interpretam a identificação partidária como um meio utilizado pelo eleitor para diminuir os custos da obtenção e processamento de informaçóes políticas, uma espécie de "ponte" ou atalho para a tomada de decisóes. Ao observar o comportamento dos partidos em determinadas ocasiôes, o eleitor avaliaria se tal ação está em conformidade com os seus interesses e, desta forma, poderia, em uma próxima eleição, utilizar este conhecimento adquirido previamente, a fim de diminuir os custos informacionais e economizar tempo e recursos cognitivos. Os partidos seriam encarados como pontos de referência, aos quais os eleitores recorreriam quando necessário. Assim, a IP não seria simplesmente fruto de um processo afetivo ou de socialização, como propóe a teoria psicossociológica, mas também o resultado de um processo de decisão racional (DOWNS, 1957).

Fiorina (1981) traz novos elementos ao debate ao destacar que, se a socialização do eleitor tem peso significativo no desenvolvimento da identificação partidária, a avaliaçáo que o indivíduo realiza enquanto eleitor em sua vida adulta, ao participar das eleiçôes, tem peso maior ainda. Se o indivíduo forma sua identificação partidária durante sua socialização, na medida em que ele inicia sua experiência política como eleitor, a IP passa a ser alterada pelas suas experiências e avaliaçóes sobre o mundo político. Tal interpretação permite compreender as mudanças nas taxas de IP em razão das avaliaçôes dos eleitores.

Mais recentemente, parte relevante da literatura internacional tem evidenciado o aumento dos níveis educacionais pós Segunda Guerra Mundial como um fator condicionante na identificação de cidadãos contemporâneos cognitivamente mais engajados (DALTON, 1984; INGLEHART, 1990). Há apontamentos de que a participação partidária é uma forma de mobilização em que se associam, em maior medida, cidadãos mais escolarizados, que se entendem como politicamente relevantes, com maior proximidade dos assuntos políticos e mais acesso à informação e também mais ativos em termos eleitorais e associativos (DALTON, 2013).

Adotando a cogniçáo como fator fundamental, esse último pesquisador inclusive propóe uma taxinomia desse novo eleitorado dividido em quatro tipos. $\mathrm{O}$ primeiro seria o dos independentes, eleitores não ligados a partidos e sem sofisticação cognitiva, que demonstram menor preocupação com as questóes políticas e os candidatos, bem como menor propensão a votar. Os apartidários compóem a 
segunda categoria, reunindo indivíduos que possuem sofisticação cognitiva e se orientam por suas próprias competências, sem depender de rótulos partidários. A terceira categoria, dos partidários rituais, é composta por eleitores que expressam identificação com determinado partido, são guiados por eles na ausência de recursos cognitivos e os apoiam nas eleiçóes, mas possuem conhecimento restrito sobre as questôes políticas. Por fim, temos a categoria dos partidários cognitivos, eleitores partidários, mais esclarecidos politicamente, com mais acesso a informaçóes políticas e mais mobilizados cognitivamente.

De acordo com Dalton e Wattenberg (2000), o crescimento do nível educacional contribuiu para o aumento dos recursos cognitivos e políticos dos cidadãos e, consequentemente, aguçou seu interesse pelos assuntos da vida pública. Com maior desenvolvimento cognitivo e maior acesso à informação, o eleitor estaria se tornando autossuficiente para avaliar o jogo político, configurando um processo em que a mobilizaçáo cognitiva estaria contribuindo, no campo da política, para o processo de dealignment partidário.

Como o conjunto dessas interpretaçóes tomaram como objeto empírico a realidade das democracias consolidadas do Hemisfério Norte, a seguir, procuramos avaliar, em diálogo com a literatura nacional e com dados referentes a amostras representativas da populaçáo brasileira, a configuração dessa relaçáo entre a cidadania e as instituiçôes partidárias em nossa ainda jovem democracia.

\section{Identificação partidária no cenário nacional}

No que se refere ao Brasil, as afirmaçóes sobre o declínio e a volatilidade das taxas não diferem dos diagnósticos internacionais. No período democrático de $1945 \mathrm{a}$ 1964 , o percentual de identificados girava em torno de 64 pontos e atingiu cerca de $70 \%$ durante o período do bipartidarismo imposto pelo Regime Militar (LAVAREDA, 1991; BRAGA; PIMENTEL JUNIOR, 2011). No entanto, após o processo de redemocratização do Brasil, esse indicador iniciou um processo de declínio e volatilidade, assumindo, na maior parte do período, um contingente menor que $50 \%$ dos eleitores. 
Gráfico 1 - Identificação partidária (1989-2016)

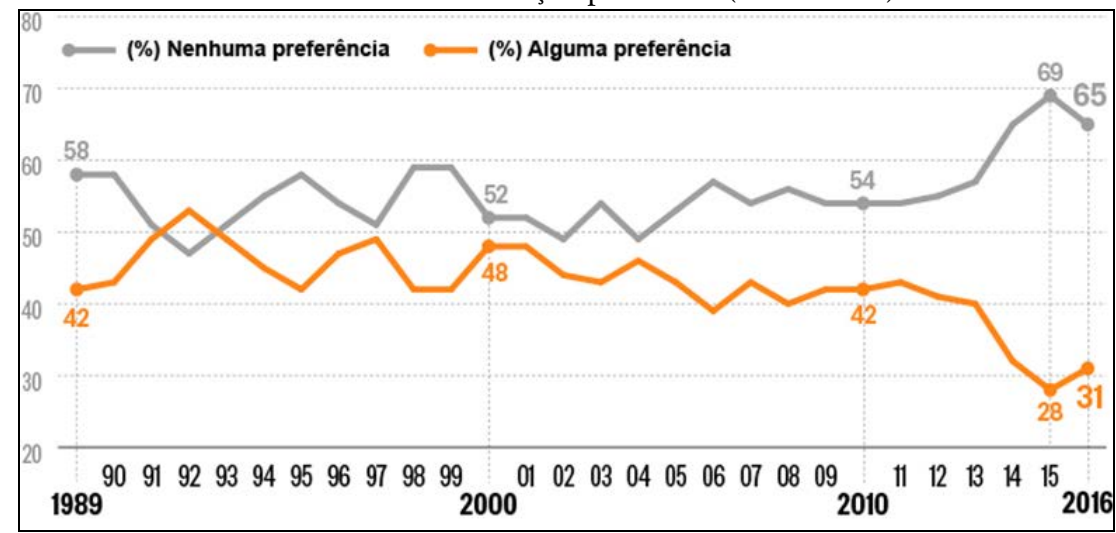

Fonte: Vasconcelos (2016), com dados do DataFolha (1989-2016).

O gráfico 1 contém os dados de pesquisas nacionais realizadas pelo instituto de pesquisa DataFolha e apresenta o monitoramento longitudinal da identificação partidária no período de 1989 a 2016, tornando possível observar a trajetória das taxas de IP, a qual pode ser analisada em duas partes: a primeira corresponde ao período até 2001, quando houve grande volatilidade do índice; a segunda diz respeito ao período de 2002 até o presente, caracterizado pelo declínio da IP, especialmente a partir de 2013, quando irrompeu negativamente a linha dos 40 pontos, atingindo $28 \%$ em 2015 e $31 \%$ em levantamento realizado no fim do primeiro quadrimestre do ano corrente.

Carreirão e Kinzo (2004) expõem alguns fatores que consideram responsáveis pela redução da IP após a redemocratização. Em primeiro lugar, o fato de algumas funçóes que eram tradicionalmente executadas pelos partidos passarem a ser efetuadas por outras instituiçóes, sendo o exemplo categórico o papel exercido pelos meios de comunicação nas campanhas eleitorais. Em segundo lugar, o aumento na escolaridade e a ampliação do acesso à informação através dos novos meios de comunicação fizeram com que as novas geraçôes aumentassem sua capacidade de absorver as informaçóes políticas, sem a necessidade de usar os partidos como atalhos de informação. Os autores também apontam para a existência de uma avaliação predominante entre os estudos que apontam para a diminuiçáo da relevância dos partidos na decisão do voto.

Braga e Pimentel Junior (2011), entretanto, advogam contra a ideia de que os partidos não são importantes para a explicação do comportamento eleitoral. De acordo com os autores, mesmo que os partidos náo estejam internalizados em termos 
de identificação partidária, eles ainda constituem uma variável importante para a compreensão do comportamento do eleitor e de sua decisão. Para demonstrar a situaçáo do partidarismo no Brasil, os autores realizam uma comparação entre o cenário nacional e o internacional, por meio de uma listagem das médias de IP de várias democracias entre os anos de 1996 a 2000 e de 2000 a 2005. Partindo disto, revelam que a conexão entre eleitores e partidos, no Brasil, se comparada a outras naçôes, não nos coloca em uma posição tão negativa quanto à visão exposta por alguns estudiosos, já que o país se encontra um pouco acima da média mundial, somando $49,5 \%$ de 2000 a 2005 . Vale ressaltar que, em relaçáo às democracias consolidadas, o Brasil se encontra muito próximo de países como Grã-Bretanha, Dinamarca, Noruega, Suécia, Finlândia e Irlanda, e ainda apresenta percentuais superiores aos de Japão, Alemanha, Coréia do Sul, Bélgica e Holanda.

Vários estudos empíricos recentes se ocupam em analisar as condiçóes favoráveis à identificação e às manifestações que sentimentos positivos em relação a essas instituiçôes despertam no eleitor, considerando que essa ainda é uma medida eficiente para a compreensão do comportamento eleitoral. Veiga (2011), ao analisar as oscilaçôes presentes no período de 2002 a 2010, monitora as continuidades e alteraçóes no perfil dos eleitores partidários e constata que, em um curto período, o perfil desses eleitores sofreu consideráveis alteraçōes. O eleitor partidário, no ano de 2010, encontra-se mais escolarizado que em 2006, mais localizado no Norte, CentroOeste e Nordeste e, em termos de posicionamento ideológico, mais próximo do centro-esquerda e centro-direita.

Outra análise sobre o período é realizada por Ribeiro, Carreirão e Borba (2011), com o objetivo de identificar a existência de relaçáo entre os sentimentos partidários e variáveis de caráter atitudinal e comportamental. Os autores verificaram que, em 2010, os sentimentos partidários estavam relacionados positivamente com tais variáveis; porém, tal relação ocorria com maior grau de intensidade nas atitudes do que no comportamento político dos eleitores.

Sobre a onda de protestos que se estende desde 2013 até 2016, ainda não há artigos conclusivos ou sequer que apontem indícios para analisarmos a relação entre manifestaçôes partidárias e contestação. Dados coletados pelo World Values Survey demonstram que houve incremento menor do que $2 \%$ na taxa de brasileiros que participaram de protestos em 2013 com relação a períodos anteriores. Sabe-se que, especialmente a partir de 2014 e com maior intensidade em 2015 e no primeiro quadrimestre de 2016, os protestos assumiram caráter de ataque ou defesa do governo vigente, uma vez que, majoritariamente, foram convocados e organizados por grupos 
e argumentos favoráveis, por um lado, ao impeachment da presidenta Dilma Rousseff e à prisão de dirigentes e políticos petistas, por exemplo, e, por outro lado, defensores da presidenta e de seu governo, que reividicavam também a expansão das investigaçóes de corrupção a outros partidos e grupos políticos. De modo geral, o saldo desse momento político é o espraiamento da visão negativa de políticos, de partidos e da política no Brasil.

Em que pese o fato de que a maior parte dos eleitores nacionais com alguma IP se identifica com o PT, faz-se relevante destacar que as alteraçóes nas características do eleitorado petista influenciam, em alguma medida, o perfil do conjunto de brasileiros que se identificam com partidos políticos. Enquanto maior e mais organizado partido de esquerda latino-americano (AMARAL, 2010) e destacado como "espinha dorsal do sistema partidário brasileiro" (SINGER, 2000), um dos diferenciais do PT seria sua capacidade de penetração de informaçóes junto ao eleitorado, o que teria contribuído para a conduçáo do partido à Presidência ${ }^{2}$, especialmente em 2002, quando a base petista era composta por indivíduos mais escolarizados (KINZO, 2007; SINGER, 2010; 2012; VEIGA, 2011). Nesse sentido, no que se refere ao período entre 2002 e 2006, autores como Veiga (2007; 2011), Singer $(2010$; 2012) e Venturi (2010) identificaram uma importante alteraçáo na base do eleitorado petista por conta do menor índice de escolarização verificado no ano de reeleição de Lula, num processo de popularização do partido (RIBEIRO, 2003; SINGER, 2010; VENTURI, 2010). No entanto, Singer (2010; 2012) destaca que tal processo se iniciou antes mesmo das eleiçóes de 2002, de modo que, nos períodos subsequentes, se deu uma expansão de sua popularização, em virtude, dentre outros fatores, da perda de simpatia da classe média pelo partido e do apoio das classes mais populares em decorrência das políticas sociais implementadas pelo Governo Federal no período.

\footnotetext{
2 Telles (2003) destaca que as coligações estabelecidas pelo PT para o pleito majoritário de 2002 lhe conferiram melhores condições de competir eleitoralmente. Ribeiro (2003) e Couto, Abrúcio e Teixeira (2013) afirmam ainda que o desgaste sofrido pelo PSDB com relação a problemas econômicos no segundo mandato de Fernando Henrique Cardoso também influenciaram o resultado final da eleição de 2002.
} 


\section{Evolução do perfil socioeconômico do eleitor partidário no Brasil (2002-2014)}

Esta seçáo procura analisar o perfil socioeconômico do eleitor partidário nas eleiçóes de 2002, 2006, 2010 e 2014. Para tal, foram propostos dois modelos de regressáo para cada ano, em que o primeiro procura identificar que atributos socioeconômicos impactam a identificação, enquanto o segundo compara esses efeitos entre os partidos selecionados para a análise.

A Tabela 2 (abaixo) apresenta os resultados de modelos de regressão logística binária referentes à identificação partidária, que tomam como possíveis preditores os atributos fundamentais: sexo, faixa etária, escolaridade e renda individual para os anos de 2002, 2006, 2010 e $2014^{3}$.

Tabela 2 - Preditores socioeconômicos da identificação partidária no Brasil (2002-2014)

\begin{tabular}{l|c|c|c|c}
\hline \multirow{2}{*}{ Sexo } & \multicolumn{4}{|c}{$\operatorname{Exp}(B)$} \\
\cline { 2 - 5 } & $\mathbf{2 0 0 2}$ & $\mathbf{2 0 0 6}$ & $\mathbf{2 0 1 0}$ & $\mathbf{2 0 1 4}$ \\
\hline Faixa etária & $1,252^{*}$ & 1,451 & $1,312^{*}$ & $1,374^{*}$ \\
\hline Escolaridade & 1,001 & 1,238 & 0,915 & 1,021 \\
\hline Renda individual & $1,221^{*}$ & 1,192 & 1,098 & 1,074 \\
\hline Constante & 1,056 & 1,002 & 1,000 & 1,073 \\
\hline$\%$ de acertos & $0,348^{* *}$ & 0,155 & 0,594 & 0,222 \\
\hline
\end{tabular}

Notas: ${ }^{*}$ sig $\leq 0,050 ;{ }^{* *}$ sig $=0,001$.

Fonte: ESEB (2002, 2006, 2010, 2014).

A variável escolaridade apresentou efeito positivo sobre a IP somente em 2002. Observando o exponencial de Beta, é possível verificar que cada elevação no grau de escolarização dos brasileiros elevava em $22,1 \%$ as chances daquele indivíduo ter identificação com alguma legenda partidária naquele ano. Tal variável é entendida como fator essencial para o engajamento cognitivo (DALTON, 2013) e para a competência cívica do eleitor (WITHELEY, 2011). Nesse sentido, o aumento nas taxas de escolarização tem sido apontado como um dos fatores explicativos do desalinhamento entre cidadãos e partidos, já que o eleitor mais escolarizado dependeria menos dessas instituiçóes para a tomada de decisões (BAQUERO, $2000)^{4}$.

\footnotetext{
${ }^{3}$ Informaçóes técnicas sobre as variáveis encontram-se no apêndice metodológico.

${ }^{4}$ Segundo Dalton (2013), estaria em curso o fortalecimento de um novo tipo de eleitor nos Estados Unidos e em democracias consolidadas europeias, fortemente interessado por política, que apoia a
} 
À exceção de 2006, em que não foram observados valores estatisticamente significativos no modelo, a variável sexo se destaca como relevante preditora da identificação partidária entre os brasileiros. Nos demais períodos, o fato de ser homem elevou em medida crescente as chances de manifestação de IP: 25,2\% em 2002, 31,2\% em 2010 e 37,4\% em 2014. Sáo muitos os autores que apontam para existência de uma sobrerrepresentação masculina no engajamento partidário (HEIDAR, 2006; NORRIS, 2011; RIBEIRO, 2011; WHITELEY, 2011; VAN BIEZEN, MAIR e POGUNTKE, 2012) e entendemos aqui que a identificação mostrou um efeito semelhante, ainda que se trate de uma disposição à aproximaçáo e não de participaçáo efetiva em partidos.

Por fim, destacamos que a faixa etária e a renda individual dos entrevistados não atingiram níveis de significância estatística suficientes $(<0,05)$ para a sua identificação como preditores relevantes, o que denota não constituírem recursos relevantes à manifestaçáo de IP entre os brasileiros ao longo do período analisado.

Tomados em conjunto, os resultados dos quatro modelos indicam que os atributos socioeconômicos dos cidadáos nacionais são pouco relevantes na explicação do partidarismo, com exceção do sexo. Essa conclusão nos afasta significativamente das explicaçôes que associam o desalinhamento à melhoria de indicadores como renda e escolaridade (DALTON, 2013) ou idade (INGLEHART e WELZEL, 2005), uma vez que, em nosso contexto, não existem evidências de diferenciação no perfil de identificados e não identificados, pelo menos no tange a tais atributos.

Para verificar se tais diferenças se manifestariam de alguma forma entre os partidários de diferentes legendas nacionais, continuamos nossas análises com a produção de modelos de regressão multinomial para os quatro anos aqui analisados, levando em consideração as principais legendas nacionais em cada período: apenas PT, PSDB e PMDB em 2002 e 2006, com inclusão do PV em 2010 e expansão do modelo ao PSB em 2014. Em todos os modelos, o PT foi utilizado como categoria de referência, tanto por agregar o maior contingente de eleitores identificados com a legenda, quanto por ser o partido vitorioso nos pleitos.

democracia e goza de alta cognição; mas, por outro lado, não utiliza os partidos como balizadores de seus posicionamentos e opinióes sobre política: o eleitor apartidário. No caso brasileiro, assim como para um amplo conjunto de 22 países latino-americanos, para os quais há dados representativos disponibilizados pelo Latin American Public Opinion. Project (LAPOP) referentes ao período entre 2008 e 2014, Gimenes (2015) não verificou variaçóes nos perfis de apartidários para além das margens de erro das pesquisas. 
Tabela 3 - Preditores sócio-econômicos da identificação partidária no Brasil, por partidos (2002-2014) a

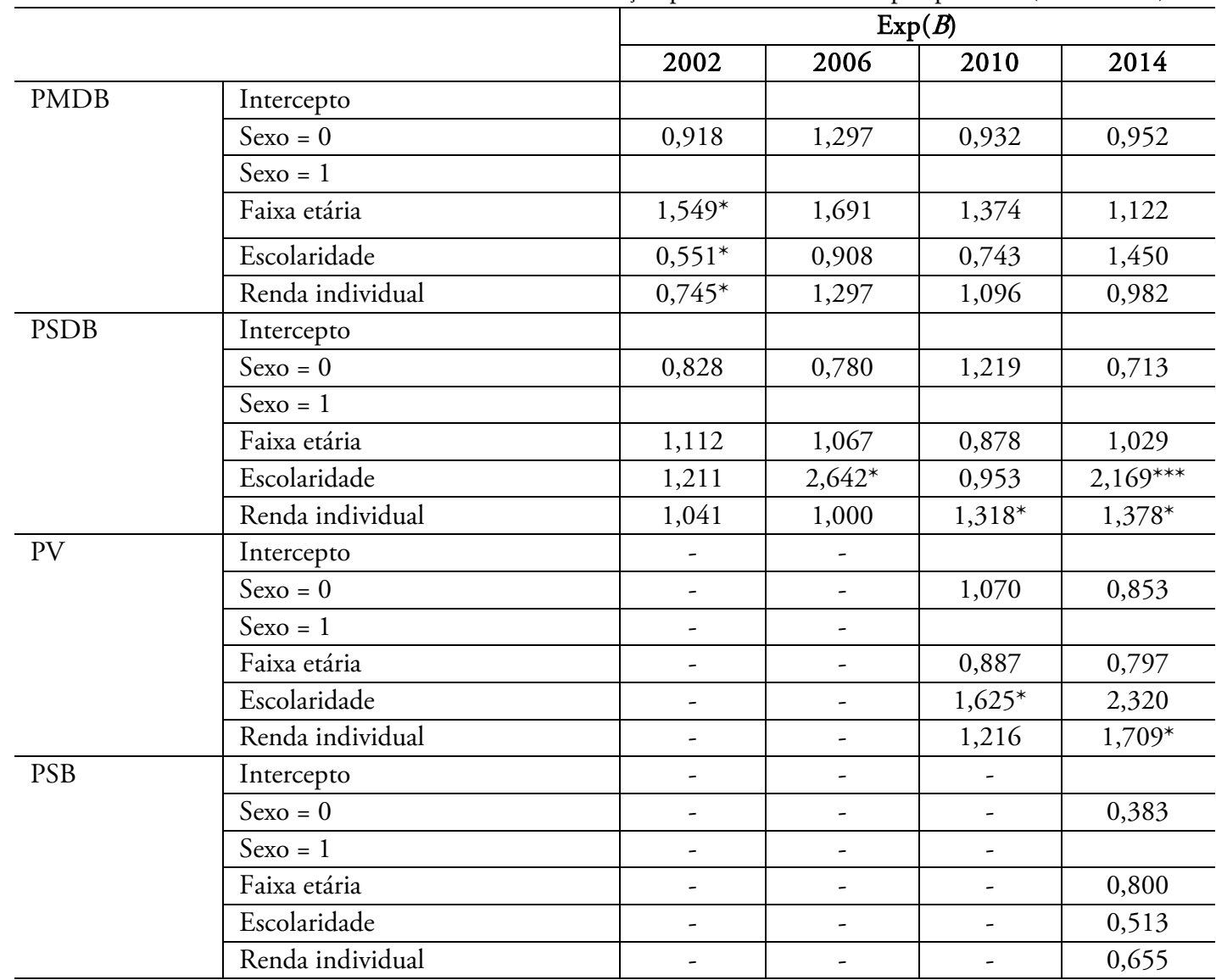

${ }^{a}$ Categoria de referência: PT.

Notas: ${ }^{*}$ sig $\leq 0,050 ;{ }^{* * *}$ sig $=0,000$.

Fonte: ESEB (2002, 2006, 2010, 2014).

Considerados os dados referentes ao modelo de 2002, observamos que cada avanço na escala de faixas etárias eleva em $2,4 \%$ a chance de identificação com o PMDB, comparada à chance de se identificar com o PT. No que se refere à escolaridade, cada elevaçáo no grau de instrução diminui em 44,9\% essa mesma chance comparativa de identificação. A variável renda também apresentou efeito negativo, uma vez que cada nível adicional de rendimentos diminui em $25,5 \%$ a chance de identificação do eleitor como peemedebista, frente aos petistas. Em síntese, quando comparados aos identificados com o PT, os eleitores que se identificam com 
PMDB tendem a ser mais velhos, menos escolarizados e possuir menor renda no que diz respeito aos dados de 2002 .

Como o mesmo modelo revela, no caso do PSDB, nenhuma das variáveis apresentou o nível mínimo de significância exigido $(0,05)$, o que representa algo relevante para nossos interesses de pesquisa, já que indica a inexistência de diferenciais consideráveis em termos de idade, escolaridade, renda ou sexo entre identificados com PT e PSDB naquele ano.

No ano de 2006, o índice de IP sofreu uma severa queda de 11,2 pontos, segundo os dados do ESEB, somando $28 \%$ no total de eleitores brasileiros. Não existem trabalhos que indiquem, de maneira concreta, os fatores que levaram a esta queda; porém, alguns autores apontam o escândalo do "mensaláo" como um dos responsáveis (VEIGA, 2011; RIBEIRO; CARREIRÃO; BORBA, 2011). Hipóteses semelhantes foram também propostas em trabalhos internacionais, associando conflitos e escândalos políticos ao aumento de eleitores independentes, afastados dos partidos (DALTON, MCALLISTER e WATTENBERG, 2003). Para além dessa redução significativa na IP, verificamos, nos dados de 2006, contingente expressivo de respostas ausentes na questáo sobre renda individual, o que reduziu o número de casos incluídos no modelo a apenas 110, o que implica em parcimônia nas constataçóes decorrentes. Contudo, dado que o modelo não se apresenta discrepante com relação aos resultados comparados dos demais anos, optamos por sua análise neste ponto da investigaçáo.

Nesse modelo, não há distinçôes estatisticamente significativas entre eleitores identificados com PT e com PMDB. Já o PSDB apresentou uma grande diferença na variável escolaridade: a cada elevação de nível de escolarização, aumenta em 164,2\% a chance do eleitor partidário ser simpático ao PSDB em vez de identificado com o PT, ou seja, em 2006 o eleitor peessedebista tendia a ser consideravelmente mais escolarizado do que o eleitor petista. As demais variáveis também não foram distintivas entre PSDB e PT.

Nas eleições de 2010, as taxas de IP recuperaram os pontos perdidos em 2006, representando também o fortalecimento da relação entre eleitores e partidos. Segundo Veiga (2011), o PT foi o partido mais eficiente em se tratando da recuperaçáo do partidarismo entre o eleitorado brasileiro no período de 2006 a 2010, e seu eleitorado apresentou leve aumento de escolaridade, que havia decaído em 2006, enquanto os eleitores do PSDB e do PMDB permaneceram estagnados. O PV não foi objeto de análise da autora. 
No entanto, a pequena indiferenciação entre os identificados com distintas legendas, que constatamos com os dados de 2006, se repete no modelo para o ano de 2010. Seus resultados apontam, novamente, que identificados com PT e PMDB não se diferenciam em termos socioeconômicos, o que pode decorrer, em alguma medida, do fato de que tais partidos realizaram uma coligação para a disputa presidencial, o que contribuiria para a inexistência de diferenças significativas entre os perfis de seus eleitores.

Por outro lado, aqueles que manifestam IP com o PSDB se distinguem de petistas somente no que diz respeito à renda individual, sendo que cada acréscimo na escala de rendimentos eleva em $31,8 \%$ a chance do eleitor se identificar com o PSDB ao invés do PT. Em contrapartida, a escolaridade deixou de ser significativa à diferenciação entre identificados com esses partidos.

Quanto ao PV, verificou-se a capacidade preditiva da escolaridade: o eleitor simpático ao partido, se comparado aos petistas, tem maior nível educacional. A cada elevação no grau de escolarização dos brasileiros, temos o incremento de $62,5 \% \mathrm{da}$ chance de que se trate de um indivíduo identificado com o PT, quando em comparação com o PT.

O ano de 2014 foi caracterizado por eleiçóes presidenciais muito disputadas, nas quais os candidatos de PSDB e PSB pleitearam a possibilidade real de disputar o segundo turno com a candidata petista, uma vez que pesquisas eleitorais realizadas ao longo do período de campanha oscilaram entre Marina Silva, especialmente no momento inicial da campanha (por conta, dentre outros aspectos, do falecimento do candidato do PSB à presidência naquele momento, Eduardo Campos, em acidente aéreo), e Aécio Neves, na reta final da campanha.

Tal cenário esteve atrelado ao afastamento de parte do eleitorado com relação aos partidos desde o ano anterior, quando irromperam manifestaçóes de rua em mais de cem municípios de todos os tamanhos e regiōes, inicialmente mobilizados pela manutenção das tarifas do transporte público e/ou pela gratuidade do transporte coletivo (capitaneadas pelo Movimento Passe Livre - MPL). Em um segundo momento, um amplo conjunto de pautas tomou as ruas, dentre as quais se destacaram discursos contrários aos partidos e até mesmo à persistência do regime democrático (MARICATO, 2013; ROLNIK, 2013; SINGER, 2013). Segundo dados do ESEB, em 2014, o percentual de brasileiros que se sentia representado por partidos políticos decresceu a $26,2 \%$.

Em termos de diferenciação intra-partidos, novamente não verificamos, no modelo, discrepâncias entre aqueles identificados com o PT e o PMDB, o que pode 
decorrer, em alguma medida, da persistência da coligação entre tais partidos na disputa presidencial.

Com relação ao PSDB, o efeito da escolaridade volta a se destacar (como verificado em 2006) de maneira expressiva: comparados petistas e peessedebistas, indivíduos com maior nível de escolarização têm aumentos de 116,9\% das chances de manifestarem IP com o PSDB a cada grau de escolaridade atingido. Ademais, percebemos que o efeito significativo e positivo da renda individual permanece, de modo que, quanto maior o rendimento do eleitor, maior a possibilidade de que ele se identifique com o PSDB ao invés do PT, na proporção de 37,8\% de elevação de chance a cada acréscimo no nível de renda.

Também para o PV, verificamos efeito significativo da renda individual, com intensidade maior do que a verificada na comparação anterior: cada incremento na faixa de rendimento individual dos eleitores corresponde à elevação de $70,9 \%$ da chance de sentir IP com o PV, em comparação com o PT. Por fim, não verificamos efeitos significativos que diferenciassem, em termos socioeconômicos, eleitores identificados com o PT e com o PSB.

Em termos gerais, permanece, em 2014, a baixa capacidade explicativa de sexo, faixa etária, renda individual e escolaridade para a IP manifestada pelos brasileiros com relação ao PT, PSDB, PMDB, PV e PSB. Além disso, não verificamos semelhanças entre os efeitos referentes aos eleitores do PV de Marina Silva em 2010 e aqueles do PV e do PSB (partido pelo qual a mesma Marina fora candidata na última eleição) em 2014.

Em síntese, quanto à comparação entre os partidos, apesar de algumas diferenças nos identificados com o PMDB em 2002, com o PSDB em 2006, 2010 e 2014 e com o PV em 2010 e 2014, os resultados apontam para uma tendência geral de indiferenciação entre as cinco legendas, haja vista a inconstância na verificação de capacidade preditiva de sexo, faixa etária, escolaridade e renda individual sobre a IP. Nesse sentido, nosso entendimento é de que tal resultado é de grande relevância à discussão sobre o partidarismo no Brasil, uma vez que pesquisas empíricas anteriormente empreendidas destacam a distinção entre eleitores do PT e do PSDB, o que não verificamos de maneira contundente em nossa análise até aqui. Ainda que tais pesquisas tenham focado especificamente o comportamento eleitoral, objeto analítico distinto do abordado neste paper, faz-se salutar destacar a necessidade de questionamento das bases de diferenciação de partidários das referidas legendas, ponto relevante para composição da agenda de pesquisa da Ciência Política nacional, 
especialmente pela polarização exercida por PT e PSDB nos sistemas eleitoral e partidário brasileiros.

\section{Evolução do perfil atitudinal do eleitor partidário no Brasil (2002-2014)}

$\mathrm{Na}$ seção anterior, procuramos apresentar um panorama sobre o perfil socioeconômico dos eleitores partidários nas eleiçóes de 2002, 2006, 2010 e 2014, bem como sobre as diferenças existentes entre eleitores dos partidos PT, PMDB, PSDB, PV e PSB. Nesta seção, apresentamos resultados de modelos de regressão logística binária e multinomial que objetivaram analisar algumas questôes cognitivas e atitudinais relacionadas à identificaçáo, apontadas pela literatura recente.

A Tabela 3 evidenciou que, em 2002, os eleitores partidários eram mais escolarizados que os eleitores não partidários; porém, nos anos de 2006 e 2010, essa relação não se verificou. Ainda que a variável escolaridade seja considerada como um recurso necessário para o engajamento cognitivo, existem outros requisitos, como o interesse por política, o conhecimento sobre política e o acesso à informação, que contribuem para a formação de um eleitor mais racional e, consequentemente, mais interessado no desenvolvimento democrático.

Dalton (2013), por exemplo, identificou que os norte-americanos têm decidido seu voto cada vez mais próximo ao pleito, de modo que discussôes sobre política, a busca por informaçóes e a capacidade de autoavaliação sobre o conhecimento político têm se tornado cada vez mais características associadas ao refinamento cognitivo do eleitorado. Uma medida utilizada pelo autor para medir a mobilização cognitiva é construída a partir da junção entre as variáveis escolaridade e interesse por política numa escala de mobilização cognitiva. No ESEB 2010, não existe a questão sobre interesse por política. Entretanto, para a realização dos testes, utilizamos outra variável também considerada relevante por Dalton (2013) à mensuração dos níveis de cognição política dos eleitores, qual seja: a frequência de obtenção de informaçóes.

Outro ponto relevante levantado por esse mesmo autor diz respeito à falsa associação entre enfraquecimento dos partidos e queda no comparecimento eleitoral. Eleitores não partidários (mas politicamente sofisticados) se aproximariam mais do cidadão racional, de modo que, mesmo não tendo um partido de preferência, votariam realizando um julgamento sobre os candidatos para a escolha do mais qualificado. Sendo assim, a queda nas taxas de IP não conduziria automaticamente à diminuição do comparecimento eleitoral ou da importância atribuída ao voto pelos 
eleitores, ao menos no que se refere àqueles de perfil apartidário. Tendo em vista os apontamentos do autor, nessa seção, procuramos verificar se, entre o público nacional, também se sustenta a hipótese da relação positiva entre partidarismo e atitudes e disposiçóes cognitivamente mobilizadas para o campo político e a valorização do voto. Nesse sentido, consideramos a capacidade de posicionamento no espectro ideológico por parte dos eleitores e sua manifestação com relação a dois indicadores de atribuição de importância ao voto, quais sejam: [1] o quanto o voto influencia o que acontece no Brasil e [2] se votaria caso não houvesse obrigatoriedade no comparecimento eleitoral.

Para a realização dos testes, foi utilizado o mesmo método da seção anterior: primeiramente, construímos modelos binários, tendo a identificação partidária como variável dependente e, posteriormente, produzimos modelos multinomiais, com vistas à comparação entre os identificados com os distintos partidos anteriormente destacados. Foram incluídas sexo, faixa etária, escolaridade e renda individual como variáveis de controle e ainda aquelas apontadas acima (busca por informação política, capacidade de posicionamento no espectro ideológico e a importância atribuída ao voto) como variáveis explicativas, a fim de captar as relaçóes entre partidarismo (ou apartidarismo) e IP, ou seja, aspectos que sintetizariam essa postura politicamente mobilizada entre os brasileiros.

Os modelos binários seguem expostos na Tabela 4. Faz-se relevante ressaltar que o volume considerável de dados faltantes em 2006 nos obrigou a excluir esse período da análise, bem como que os questionários dos ESEBs de 2002, 2010 e 2014 apresentaram algumas questóes diferentes, de modo que foram utilizadas proxys, conforme exposto no apêndice metodológico.

Tabela 4 - Preditores sócio-econômicos e atitudinais da identificação partidária no Brasil (2002-2014)

\begin{tabular}{l|c|c|c}
\hline \multirow{2}{*}{ Sexo } & \multicolumn{3}{|c}{$\operatorname{Exp}(B)$} \\
\cline { 2 - 4 } & $\mathbf{2 0 0 2}$ & $\mathbf{2 0 1 0}$ & $\mathbf{2 0 1 4}$ \\
\hline Faixa etária & 1,094 & 0,906 & 1,180 \\
\hline Escolaridade & 1,100 & 0,898 & 0,991 \\
\hline Renda individual & 1,010 & 1,049 & 1,015 \\
\hline Frequência de informação & 1,000 & 0,913 & 1,015 \\
\hline Capacidade de posicionamento ideológico $^{\text {Cany }}$ & $1,104^{* * *}$ & $1,064^{* * *}$ & 0,982 \\
\hline Importância atribuída ao voto I $^{a}$ & $1,136^{*}$ & $1,628^{* * *}$ & $1,955^{* * *}$ \\
\hline Importância atribuída ao voto II $^{\mathrm{b}}$ & $1,228^{* * *}$ & $1,117^{*}$ & $1,173^{* *}$ \\
\hline Constante & $1,908^{* * *}$ & $0,713^{* *}$ & $2,420^{* * *}$ \\
\hline \% de acertos & $0,155^{* * *}$ & $0,436^{*}$ & $0,080^{* * *}$ \\
\hline & 61,7 & 62,6 & 71,5 \\
\hline
\end{tabular}


a Voto influencia muito o que acontece no Brasil ou náo influencia nada?

${ }^{\mathrm{b}}$ Votaria caso o voto não fosse obrigatório no Brasil?

Notas: ${ }^{*}$ sig $\leq 0,050 ;{ }^{* * *}$ sig $=0,000$.

Fonte: ESEB (2002, 2010 e 2014).

Inicialmente, destacamos que os efeitos das variáveis socioeconômicas sobre a IP, abordados na seção anterior, desaparecem dos modelos binários quando da introdução de características atitudinais, o que nos permite inferir que sexo, faixa etária, escolaridade e renda individual não são relevantes à determinação do perfil do eleitor partidário brasileiro quando consideramos aspectos relacionados à sua mobilização cognitiva.

Em se tratando das variáveis atitudinais, estas apresentam efeitos significativos sobre o partidarismo nos três momentos analisados. Em se tratando da frequência de acesso à informaçáo, esta apresenta efeitos baixos em 2002 e em 2010 (de 10,4 e $6,4 \%$, respectivamente), o que náo se verifica em 2014. Em outras palavras, a recorrência da busca por informaçóes impactava fracamente a manifestação de IP ao longo da década anterior, mas perdeu seu efeito segundo os últimos dados do ESEB, o que pode ser indício do espraiamento do acesso às informaçóes no Brasil. Os protestos de 2013 foram amplamente caracterizados pelas articulaçóes e convocaçóes por meio de redes sociais, assim como replicado ao longo dos anos seguintes, de modo que tanto eleitores partidários quanto não partidários têm ampliado as possibilidades de acesso à informação política, bem como à informaçáo de modo geral.

Quanto à capacidade de posicionamento ideológico, Singer (2000) e Carreirão (2002) se debruçaram sobre a questão anteriormente. Enquanto o primeiro autor constatou que os brasileiros conseguiam dissernir e se posicionar entre "esquerda" e "direita", o segundo verificou que tal diferenciação e capacidade de autolocalização estava relacionada à escolarização dos eleitores, o que significaria a associação entre dois recursos de mobilização cognitiva. Em nossa pesquisa, não nos preocupamos em verificar em que ponto do espectro ideológico os eleitores se localizaram, mas apenas em distinguir aqueles com capacidade de se posicionar no espectro "esquerda-direita" daqueles para os quais tal escala não faz sentido, ou seja, binarizamos os eleitores entre aqueles que compreendem ou não posiçôes ideológicas (independente de seu conteúdo para cada um). Os resultados apontam que aqueles que têm alguma clareza sobre o espectro, manifestada por sua autolocalização em algum ponto entre "esquerda" e "direita", têm cada vez mais chances de se identificarem com partidos do que aqueles que náo gozam de tal recurso: enquanto em 2002 essa possibilidade se elevava em 13,6\%, o valor atingiu 62,8\% em 2010 e 
alcançou 95,5\% em 2014, de modo que quem é capaz de se posicionar no espectro tem quase o dobro de chances de ser partidário do que aqueles que não sabem se localizar.

As medidas relativas à valorização do voto também se mostraram preditores relevantes; porém, com intensidades bem distintas. Por um lado, a importância atribuída ao voto afeta de maneira fraca a identificação partidária no Brasil, sendo que aqueles que entendem que o voto tem muita influência gozaram de chances maiores de manifestar IP que os que percebem pouca influência $(22,8 \% \mathrm{em} 2002,11,7 \% \mathrm{em}$ 2010 e 17,3\% em 2014). Por outro lado, a disposição em votar, mesmo que o comparecimento eleitoral não fosse obrigatório, no Brasil, gerou resultados contraditórios no período: em 2002 e 2014, elevou a chance de manifestaçáo em 90,8 e $142 \%$, respectivamente, mas reduziu tal probabilidade, em 2010, em 28,7\%. Dados os distintos contextos políticos nacionais, tal resultado carece de maior aprofundamento, uma vez que, em 2010, havia relativa estabilidade política no Brasil, de modo que nossa hipótese é de que aqueles que manifestam identificação partidária entendem que o exercício do voto seria mais relevante em períodos de crises ou diante de ameaças a situaçôes que lhes assegurem determinadas posiçóes. Nesse sentido, em 2010, a disputa eleitoral ofereceu menos riscos à não-eleição de um candidato petista do que em 2002 e 2014, de modo que os eleitores identificados com o PT (cerca de $2 / 3$ do eleitorado nacional com IP) podem ter valorizado, em maior medida, seus votos como responsáveis pelo acesso (em 2002) e manutenção (em 2014) do partido na presidência.

Segundo Dalton (2013), a variável escolaridade é a mais relevante do modelo de mobilização cognitiva, não somente pelos seus efeitos cognitivos, mas também pelas oportunidades de vida, de sucesso e da possibilidade da criação de redes sociais mais extensas, uma vez que o cidadáo mais instruído detém mais recursos e habilidades para se dedicar à política. Ainda que os modelos acima expostos não demonstrem capacidade preditiva da variável de escolarização, os fatores de competência política apresentaram relaçooses explicativas significativas com os eleitores partidários.

Nesse sentido, tais resultados se filiam à tese de Dalton (2013), para quem estas variáveis são tấo importantes quanto à escolaridade para a explicação do cidadáo racional. De maneira semelhante, ainda que os modelos apresentados não tenham sido realizados sistematicamente a partir da tipologia de Dalton (2013), é possível inferir que o eleitor partidário brasileiro, de maneira geral, é mais mobilizado 
cognitivamente em termos atitudinais se comparado ao eleitor não partidário, o que nos possibilita algumas reflexóes com relação à teoria até então exposta.

Primeiramente, é possível afirmar que, no Brasil, a mobilizaçáo cognitiva ainda não tem causado, de maneira efetiva, o efeito de dealignment partidário, no qual os eleitores com graus mais sofisticados de cognição abdicam de sua ligaçáo com os partidos e passam a agir como independentes. A ausência de capacidade preditiva da variável escolaridade, nos modelos testados, pode ser analisada com um indício da existência de certa homogeneidade na distribuição de eleitores partidários e não partidários com diferentes níveis educacionais entre 2002 e 2014. Mesmo com a ausência de um perfil mais escolarizado para o eleitor que apresenta IP neste período, as variáveis de cognição apresentaram associaçóes estatisticamente significativas com o partidarismo, ressaltando que a variável utilizada como dependente nessa análise é a identificação com um partido, que pressupóe um tipo de vínculo mais forte do que simplesmente simpatizar com o mesmo.

Assim como procedemos na seçáo anterior, interessados em verificar a existência de efeitos diferenciais dessas variáveis atitudinais entre os identificados com os principais partidos nacionais, construímos modelos multinomiais. Infelizmente, dado o grande volume de dados faltantes também para a onda de 2002 do ESEB, replicamos tal procedimento apenas para os anos de 2010 e 2014.

Tabela 5 - Preditores sócio-econômicos da identificação partidária no Brasil, por partidos $(2010-2014)^{\text {a }}$

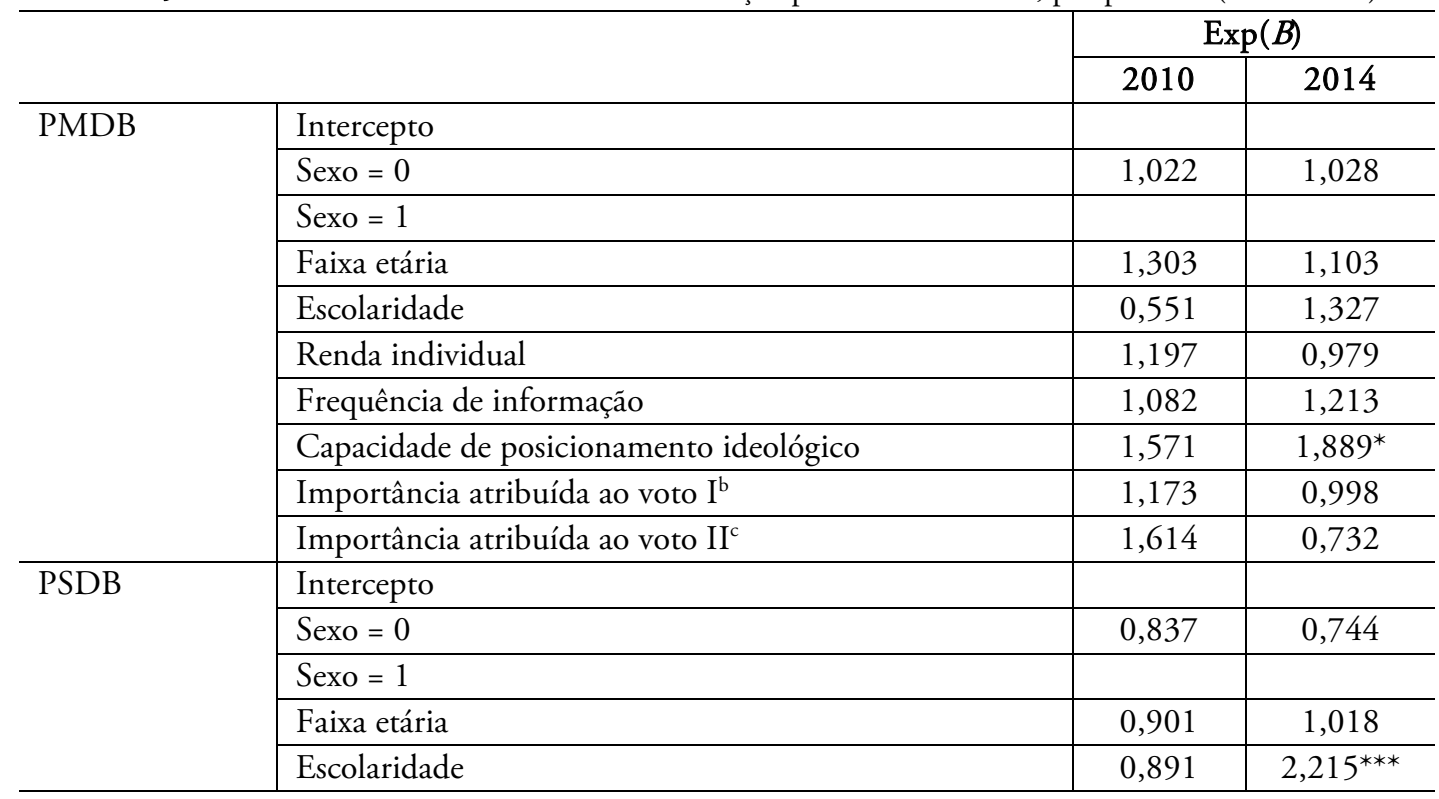




\begin{tabular}{|c|c|c|c|}
\hline & Renda individual & $1,343^{*}$ & $1,334^{*}$ \\
\hline & Frequência de informação & 1,015 & 1,114 \\
\hline & Capacidade de posicionamento ideológico & 1,371 & 1,509 \\
\hline & Importância atribuída ao voto $\mathrm{I}^{\mathrm{b}}$ & 0,996 & 0,984 \\
\hline & Importância atribuída ao voto $\mathrm{II}^{\mathrm{c}}$ & 0,938 & 0,798 \\
\hline \multirow[t]{10}{*}{ PV } & Intercepto & & \\
\hline & Sexo $=0$ & 1,073 & 0,972 \\
\hline & Sexo $=1$ & & \\
\hline & Faixa etária & 0,824 & 0,778 \\
\hline & Escolaridade & 1,575 & 2,464 \\
\hline & Renda individual & $1,297^{*}$ & $1,709^{*}$ \\
\hline & Frequência de informação & 1,033 & 1,135 \\
\hline & Capacidade de posicionamento ideológico & 0,642 & 2,353 \\
\hline & Importância atribuída ao voto $\mathrm{I}^{\mathrm{b}}$ & 0,905 & 1,207 \\
\hline & Importância atribuída ao voto $\mathrm{II}^{\mathrm{c}}$ & 1,114 & 0,308 \\
\hline \multirow[t]{10}{*}{ PSB } & Intercepto & & \\
\hline & Sexo $=0$ & - & 2,180 \\
\hline & Sexo $=1$ & - & \\
\hline & Faixa etária & - & 1,653 \\
\hline & Escolaridade & - & 1,677 \\
\hline & Renda individual & - & 1,263 \\
\hline & Frequência de informação & - & 1,411 \\
\hline & Capacidade de posicionamento ideológico & - & 3,770 \\
\hline & Importância atribuída ao voto $\mathrm{I}^{\mathrm{b}}$ & - & 18424, \\
\hline & Importância atribuída ao voto $\mathrm{II}^{\mathrm{c}}$ & - &, 0350 \\
\hline
\end{tabular}

${ }^{\text {a }}$ Categoria de referência: PT.

${ }^{\mathrm{b}}$ Voto influencia muito o que acontece no Brasil ou náo influencia nada?

${ }^{\mathrm{c}}$ Votaria caso o voto não fosse obrigatório no Brasil?

Notas: ${ }^{*}$ sig $\leq 0,050 ;{ }^{* * *}$ sig $=0,000$.

Fonte: ESEB (2010, 2014).

De maneira geral, os resultados dos modelos corroboram aqueles verificados na seção anterior. Em primeiro lugar, os efeitos socioeconômicos praticamente se mantêm, mesmo após a inserção de atributos atitudinais. Em segundo lugar, apesar de tais atributos representarem indicadores expressivos de diferenciação entre eleitores identificados e não identificados com partidos políticos no Brasil, quando buscamos distinções intra-IP não há impacto dessas variáveis, à exceção da capacidade de posicionamento ideológico como diferencial entre peemedebistas e petistas em 2014, 
quando aqueles que sabiam se posicionar no espectro ideológico gozavam de chance $88,9 \%$ maior de pertencer ao primeiro grupo do que ao segundo.

Desta maneira, os resultados expostos nesta seção corroboram aqueles anteriormente apresentados de que a diferenciação do eleitorado brasileiro se dá entre aqueles que manifestam e os que não manifestam identificação com partidos políticos, tanto em termos socioeconômicos quanto atitudinais. Contudo, quando buscamos evidências de ambas as naturezas para distinguir os perfis de partidários do PT, do PSDB, do PMDB e mais recente do PV e do PSB, os testes apontam que tais indivíduos são muito semelhantes, especialmente no que tange aos recursos cognitivos e políticos analisados, ou seja, independente do partido com o qual se identificam, os eleitores que manifestam IP acessam veículos de informaçôes com frequência similar, sabem se posicionar no espectro ideológico em medida próxima, entendem da mesma maneira que o voto influencia os acontecimentos no país e manifestam disposição semelhante em votar mesmo se o voto fosse facultativo.

\section{Considerações finais}

A volatilidade e a queda nas taxas de identificação partidária têm levado alguns trabalhos a desconsiderar sua importância enquanto medida para a análise do comportamento eleitoral. Entretanto, tal visão está longe de ser predominante, já que vários autores apontam para a importância do partidarismo e também para a necessidade de compreensão do eleitor que expressa identificação partidária (VEIGA, 2011; RIBEIRO, CARREIRÃO e BORBA, 2011; BRAGA e PIMENTEL JUNIOR, 2011; GIMENES, 2015). Assim, considerando a importância dos partidos para a compreensão do sistema eleitoral e também a necessidade de avançar na investigação sobre quem é o eleitor que expressa a IP, o presente paper buscou verificar como se associam as dimensôes da identificação partidária, das condiçóes socioeconômicas, atitudinais e cognitivas dos eleitores brasileiros.

Em se tratando de variáveis socioeconômicas, verificamos a influência da escolaridade sobre a diferenciação entre partidários e não partidários apenas em 2002, o que significa que esta medida de mobilização cognitiva não se configura atualmente em preditor do partidarismo no Brasil. Entre as demais variáveis, destaca-se a sobrerrepresentaçáo masculina entre os eleitores partidários em praticamente todo o período, o que coaduna com a literatura sobre participação política. Entretanto, nos modelos que buscaram distinguir eleitores identificados com PT, PSDB, PMDB, PV e PSB, verificamos uma tendência de indiferenciação, especialmente entre aqueles que manifestaram IP com as duas principais (e historicamente antagônicas) legendas 
nacionais, o que certamente demanda uma investigação específica e mais aprofundada.

Considerando a inserção de variáveis atitudinais, verificamos, entre os eleitores brasileiros, uma postura política mobilizada nos anos de 2002, 2010 e 2014, sobre a qual cabe ressaltar que os indícios de sofisticação política apontam no sentido de elevação da mobilização cognitiva dos eleitores. Contudo, mesmo após a inclusão de novas variáveis nos modelos, verificamos a recorrência da constatação dos modelos socioeconômicos, ou seja, ainda que a frequência de acesso a informaçóes, a capacidade de posicionamento no espectro ideológico e a valorização do voto sejam preditores do partidarismo, tais variáveis não são relevantes à diferenciação de eleitores identificados com as principais legendas nacionais analisadas nesta pesquisa.

Tal questão abre espaço para uma reflexão sobre o processo de dealigment partidário no Brasil, pois há afirmaçóes de que tal fenômeno estaria presente no cenário nacional desde o inicio do multipartidarismo (KINZO, 2004). Ainda que as variáveis de sofisticação política tenham se revelado relevantes para caracterizar o eleitor brasileiro que expressa IP como mais mobilizado cognitivamente, o que poderia se relacionar ao afastamento com relaçáo aos partidos (DALTON, 2013), o que se percebe no país é a volatilidade da identificação partidária ao longo do tempo, como já destacado quando da apresentação do Gráfico 1.

Ademais, este trabalho buscou demonstrar que a identificação partidária ainda é uma variável importante para a explicação do comportamento político dos brasileiros, uma vez que evidencia diferenças consideráveis entre eleitores partidários e náo partidários. Os modelos apresentados se ocuparam em explicar somente a relação explicativa de algumas variáveis socioeconômicas e de cognição política sobre o partidarismo. Todavia, a mobilização cognitiva também pressupóe o interesse por política, a eficácia política subjetiva do eleitor e sua adesáo à democracia. Tais questôes náo foram o objetivo deste trabalho devido à inexistência de tais variáveis no survey utilizado; porém, nosso entendimento é de que podem ser objeto de futuras pesquisas, uma vez que representam indicadores importantes do comportamento eleitoral e político dos brasileiros e podem contribuir para o entendimento sobre a existência ou ausência de distinção entre identificados com diferentes partidos políticos, especialmente com PT e PSDB.

Para finalizar, é importante destacar que os resultados aqui expostos parecem confirmar as recentes teses sobre a mudança no perfil do eleitor petista nos últimos anos (SINGER, 2010; VEIGA, 2011). Em que pese o fato de nos concentrarmos na 
144 | Éder Gimenes, Wesley Furriel, Julian Borba e Ednaldo Ribeiro

identificação partidária e não no voto ou na intenção de voto, constatamos que o perfil alinhado a essa legenda está associado à menor renda, menor escolaridade e menor frequência de acesso à informação.

Dado que o Brasil se encontra entre o conjunto de novas democracias latinoamericanas, ainda com cerca de três décadas de experiência democrática e também a existência de indícios de que a persistência de tal regime, mensurada em anos (idade da democracia), é fator mais relevante à estruturação da IP do que aspectos contextuais relacionados aos sistemas político, partidário e eleitoral (GIMENES, 2015), entendemos que os resultados deste artigo contribuem também para a agenda de pesquisas sobre a existência de diferenciação entre eleitores partidários nos demais países da região. Nesse sentido, nossos resultados podem dialogar ou mesmo subsidiar futuras investigaçóes com vistas à identificação de discrepâncias em termos de recursos socioeconômicos e de mobilização cognitiva entre aqueles que manifestam IP e os que não a manifestam, bem como da existência (ou não) de perfis específicos intra-IP, ou seja, de diferentes características que expliquem eleitores identificados com determinados partidos, diferentemente do que encontramos para o caso brasileiro.

- Éder Rodrigo Gimenes é Doutor em Sociologia. Pesquisador do grupo de pequisa "Núcleo de Pesquisa em Movimentos Sociais" da Universidade Federal de Santa Catarina (NPMS - UFSC/CNPq) e do "Núcleo de Pesquisas em Participação Política" da Universidade Estadual de Maringá (NUPPOL - UEM). E-mail: ergimenes@uem.br.

- Wesley Oliveira Furriel é Mestre em Ciências Sociais. E-mail: wesley_furriel@hotmail.com.

- Julian Borba é Doutor em Ciência Política. Professor da UFSC. E-mail: julian.borba@ufsc.br

Ednaldo Aparecido Ribeiro é Doutor em Sociologia. Professor da UEM. E-mail: ednaldorib@icloud.com.

\section{Referências}

AMARAL, Oswaldo. Adaptação e resistência: o PT no Governo Lula entre 2003 e 2008. Revista 
Brasileira de Ciência Política, Brasília, n. 4, p. 105-134, jul./dez. 2010.

BAQUERO, Marcelo. A vulnerabilidade dos partidos politicos e a crise da democracia na América Latina. Porto Alegre: Universidade Federal do Rio Grande do Sul, 2000.

BRAGA, Maria do Socorro Sousa. Eleiçóes e democracia no Brasil: a caminho de partidos e sistemas partidários institucionalizados. Revista Brasileira de Ciência Política, Brasília, n. 4, p. 43-73, jul./dez. 2010.

BRAGA, Maria do Socorro Sousa; PIMENTEL JUNIOR, Jairo. Os partidos políticos brasileiros realmente não importam? Revista Opiniáo Pública, Campinas, v. 17, n. 2, p. 271-303, 2011.

CARREIRÃO, Yan de Souza. A decisão do voto nas eleiçóes presidenciais brasileiras. Florianópolis/Rio de Janeiro: Universidade Federal de Santa Catarina/Fundação Getúlio Vargas, 2002.

CARREIRÃO, Yan de Souza; KINZO, Maria. Dalva. Partidos políticos, preferência partidária e decisão eleitoral no Brasil (1989-2002). Revista Dados, v. 47, n. 1, p. 131-168, 2004.

COUTO, Cláudio Gonçalves; ABRUCIO, Fernando Luiz; TEIXEIRA, Marco Antonio Carvalho. As eleiçōes municipais de 2012 e seus efeitos nacionais. Cadernos Adenauer, v. 14, n. 2, p. 193-207, jun. 2013.

DALTON, Russell J. The apartisan American: dealignment and changing electoral politics. Washington, DC: Sage, 2013.

. Cognitive mobilization and partisan dealignment in advanced industrial democracies. Journal of Politics, n. 46, p. 264-284, 1984.

DALTON, Russell J.; McALLISTER, Ian Martin; WATTENBERG, Martin P. Democracia e identificação partidária nas sociedades industriais avançadas. Revista Análise Social, v. 38, n. 167, p. 295-320, 2003.

DALTON, Russell J.; WATTENBERG, M. P. Parties without partisans: political change in advanced industrialized democracies. Oxford: Oxford University Press, 2002.

DOWNS, Anthony. An economic theory of democracy. New York: Harper Row, 1957.

FIGUEIREDO, Marcus. A decisão do voto: democracia e racionalidade. São Paulo: Sumaré, 1991.

FIORINA, Morris P. Retrospective voting in American national elections. New Haven: Yale University, 1981.

GIMENES, Éder Rodrigo. A relação dos eleitores com partidos políticos em novas democracias: partidarismo na América Latina. 2015. 240 f. Tese de doutorado - Programa de Pós-Graduação em Sociologia Política, Universidade Federal de Santa Catarina, Florianópolis, 2015.

HEIDAR, Knut. Party membership and participation. In: KATZ, Richard S.; CROTTY, William. Handbook of party politics. Londres: SAGE, p. 301-315, 2006.

INGLEHART, Ronald. Culture shift in advanced industrial society. Princeton: Princeton University, 1990.

INGLEHART, Ronald; WELZEL, Christian. Modernizaçấo, mudança cultural e democracia: a sequência do desenvolvimento humano. São Paulo: Francis, 2009.

KINZO, Maria. Dalva. Partidos, eleiçóes e democracia no Brasil pós-1985. Revista Brasileira de Ciência Política, São Paulo, v. 19, n. 54, p. 23-54, 2004.

Os partidos no eleitorado: percepçóes políticas e laços partidários. In: KINZO, Maria Dalva; BRAGA, Maria do Socorro Sousa (Orgs.). Eleitores e representaçáo partidária no Brasil. Sáo Paulo: Humanitas, p. 19-45, 2007. 
LAVAREDA, Antonio. A democracia nas urnas: o processo partidário-eleitoral brasileiro. Rio de Janeiro: Instituto Universitário de Pesquisas do Rio de Janeiro, 1991.

MARICATO, Hermínia. É a questão urbana, estúpido! In: MARICATO, Hermínia et al (Orgs.). Cidades rebeldes. Passe livre $e$ as manifestaçôes que tomaram as ruas do Brasil. Sáo Paulo: Boitempo/Carta Maior, p. 19-26, 2013.

MAYER, Rodrigo. Os partidos como organizaçóes: um estudo comparado do PSDB \& PT. 2011.86 f. Dissertação de mestrado - Programa de Pós-Graduação em Ciência Política, Universidade Federal do Paraná, Curitiba, 2011.

NORRIS, Pippa. Democratic deficit. New York: Cambridge University, 2011.

RIBEIRO, Ednaldo Aparecido. Valores pós-materialistas e cultura política no Brasil. Maringá: Universidade Estadual de Maringá, 2011.

RIBEIRO, Ednaldo Aparecido; CARREIRÃO, Yan de Souza; BORBA, Julian. Sentimentos partidários e atitudes políticas entre os brasileiros. Revista Opiniāo Pública, Campinas, v. 17, n. 2, p. 333-368, nov. 2011.

RIBEIRO, Pedro José. Floriano. O PT sob uma perspectiva sartoriana: de partido anti-sistema a legitimador do sistema. Revista Política e Sociedade, Florianópolis, n. 3, p. 45-70, out. 2003.

ROLNIK, Raquel. Apresentação - As vozes das ruas: as revoltas de junho e suas interpretaçôes. In: MARICATO, Hermínia. et al (Orgs.). Cidades rebeldes. Passe livre e as manifestaçôes que tomaram as ruas do Brasil. São Paulo: Boitempo/Carta Maior, p. 7-12, 2013.

SAMUELS, David; ZUCCO JUNIOR, César. The power of partisanship in Brazil: evidence from survey experiments. Social Science Research Network, out. 2012. Disponível em <http://papers.ssrn.com/sol3/papers.cfm?abstract_id=1903312>. Acesso em 23 jun. 2013.

SANDES-FREITAS, Vitor Eduardo Veras de. Alianças contextuais ou nacionalizadas? Análises das coligações nas eleiçóes para prefeito em 2012. Cadernos Adenauer, v. 14, n. 2, p. 147-165, jun. 2013. SINGER, André. Brasil, junho de 2013: classes e ideologias cruzadas. Revista Novos Estudos Cebrap, n. 97, nov., p. 23-40, 2013. 2012.

Os sentidos do lulismo. Reforma gradual e pacto conservador. São Paulo: Companhia das Letras, . A segunda alma do Partido dos Trabalhadores. Revista Novos Estudos Cebrap, São Paulo, n. 88, p. 111, 2010.

. Esquerda e direita no eleitorado brasileiro. São Paulo: Universidade de Sáo Paulo, 2000.

TELLES, Helcimara de Souza. O PT e as eleiçôes: da liderança programática à base programática. In: TELLES, Helcimara. de Souza; LUCAS, João Ignácio (Orgs.). Das ruas às urnas: partidos e eleições no Brasil contemporâneo. Caxias do Sul, RS: Universidade de Caxias do Sul, p. 15- 47, 2003.

VAN BIEZEN, Ingrid; MAIR, Peter, POGUNTKE, Thomas. Going, going, ... gone? The decline of party membership in contemporary Europe. European Journal of Political Research, n. 51, p. 24-56, 2012.

VASCONCELOS, Fábio. Partido do "você não me representa". Disponível em $<$ http://infograficos.oglobo.globo.com/brasil/partido-do-voce-nao-me-representa.html>. Acesso em 13 mai. 2016.

VEIGA, Luciana Fernandes. O partidarismo no Brasil (2002/2010). Revista Opinião Pública, Campinas, v. 17, n. 2, p. 400-425, nov. 2011. 
Os partidos brasileiros na perspectiva dos eleitores: mudanças e continuidades na identificação partidária e na avaliação das principais legendas após 2002. Revista Opinião Pública, Campinas, v. 13, n. 2, p. 340-365, nov. 2007.

VENTURI, Gustavo. PT 30 anos: crescimento e mudanças na preferência partidária. Impacto nas eleiçóes de 2010. Revista Perseu: História, Memória e Política, ano 4, n. 5, p. 196-214, 2010.

WITHELEY, Paul. Is the party over? The decline of party activism and membership across the Democratic World. Party Politics, v. 17, n. 21, 2011.

Texto recebido em 16 de agosto de 2016. Aprovado em 23 de agosto de 2016. 
148 | Éder Gimenes, Wesley Furriel, Julian Borba e Ednaldo Ribeiro

\begin{tabular}{|c|c|c|c|}
\hline \multicolumn{4}{|c|}{ APÊNDICE METODOLÓGICO - Informaçóes técnicas das variáveis } \\
\hline \multirow{3}{*}{\multicolumn{2}{|c|}{$\begin{array}{l}\text { Identificaçáo partidária } \\
\text { Existe algum partido que representa a maneira como o(a) } \operatorname{sr}(a) \\
\text { pensa? }\end{array}$}} & \multirow[t]{3}{*}{ Recodificação: } & $0=$ Não tem renda individual \\
\hline & & & $1=$ Até 1 S.M. \\
\hline & & & $2=$ Até 2 S.M. \\
\hline \multirow[t]{2}{*}{ Codificação: } & $1=\operatorname{Sim}$ & & $3=$ De 2 a 5 S.M. \\
\hline & 2 = Não & & $4=$ De 5 a 10 S.M. \\
\hline \multirow[t]{2}{*}{ Recodificação: } & $0=$ Não & & $5=$ De 10 a 15 S.M. \\
\hline & $1=\operatorname{Sim}$ & & $6=$ De 15 a 20 S.M. \\
\hline \multicolumn{2}{|c|}{ Partidos PT/PMDB/PSDB [2002/2006], } & & $7=$ Mais de 20 S.M.s \\
\hline \multicolumn{2}{|c|}{ PT/PMDB/PSDB/PV [2010] e PT/PMDB/PSDB/PV/PSB } & \multicolumn{2}{|c|}{ Frequência de acesso à informaçáo [2002] } \\
\hline \multicolumn{2}{|c|}{ [2014] } & \multicolumn{2}{|c|}{ Frequência com que lê jornal } \\
\hline \multirow{3}{*}{\multicolumn{2}{|c|}{$\begin{array}{l}\text { Partido que melhor representa sua maneira de pensar } \\
\text { Codificação: Legendas partidárias e denominaçóes personalistas } \\
\text { (119 respostas) }\end{array}$}} & \multirow[t]{3}{*}{ Codificação: } & $1=$ Uma vez por semana \\
\hline & & & $2=$ Algumas vezes por semana \\
\hline & & & $3=$ Todo dia \\
\hline \multirow[t]{2}{*}{ Recodificaçăo: } & $0=$ Outras respostas & \multirow[b]{2}{*}{ Recodificação: } & $4=$ Raramente \\
\hline & $1=$ Partido selecionado) & & $0=$ Raramente \\
\hline \multicolumn{2}{|l|}{ Sexo } & & $1=$ Uma vez por semana \\
\hline \multirow[t]{2}{*}{ Codificaçăo: } & $1=$ Masculino & & $2=$ Algumas vezes por semana \\
\hline & $2=$ Feminino & & $3=$ Todo dia \\
\hline \multirow{2}{*}{ Recodificação: } & $0=$ Feminino & \multicolumn{2}{|c|}{ Frequência de acesso à informaçáo [2010/2014] } \\
\hline & $1=$ Masculino & \multicolumn{2}{|c|}{ Costuma ler jornal? } \\
\hline \multicolumn{2}{|l|}{ Faixa etária } & Assistiu telejorn & notícias nacionais essa semana? \\
\hline Codificação: & Aberta & Codificaçăo: & $1=\operatorname{Sim}$ \\
\hline Recodificação: & $1=16$ a 24 anos & & $2=$ Não \\
\hline & $2=25$ a 34 anos & Recodificação: & $0=$ Não \\
\hline & $3=35$ a 44 anos & & $1=\operatorname{Sim}$ \\
\hline & $4=45$ a 59 anos & Índice gerado & ir do somatório das respostas às duas \\
\hline & $5=60$ anos ou mais & questôes. & \\
\hline Escolaridade & & Capacidade de & namento ideológico \\
\hline Codificaçăo: & $1=$ Analfabeto/Nunca frequentou escola & Classificaçăo do & istado entre direita e esquerda \\
\hline & $2=$ Primário incompleto & Codificaçắo: & $0=$ Esquerda \\
\hline & 3= Primário completo & & $10=$ Direita \\
\hline & 4= Ginásio incompleto & & $11=$ Não sabe o que é direita ou esquerda \\
\hline & 5= Ginásio completo & & $12=\mathrm{NS}$ \\
\hline & $6=$ Colegial incompleto & & $13=\mathrm{NR}$ \\
\hline & $7=$ Colegial completo & Recodificação: & $0=$ Náo sabe[11 a 13] \\
\hline & $8=$ Ensino universitário incompleto & & $1=$ Sabe $[0$ a 10$]$ \\
\hline & 9= Ensino universitário completo & Importância d & \\
\hline & $10=$ Pós-graduação ou mais & Voto influencia & o que acontece no Brasil ou não influencia \\
\hline Recodificação: & $1=$ Sem instruçăo [1] & nada? & \\
\hline & $2=$ Fundamental $[2$ a 5$]$ & Codificaçăo: & $1=$ Influencia muito no que acontece no \\
\hline & $3=$ Médio $[6$ a 7] & & Brasil \\
\hline & $4=$ Superior ou mais $[8$ a 10$]$ & & $5=$ Não influencia nada no que acontece \\
\hline Faixa de renda & lual & & no Brasil \\
\hline Codificação: & 1= Até 1 salário mínimo (S.M.) & Recodificaçăo: & $1=$ Não influencia nada no que acontece \\
\hline & $2=$ Até 2 S.M. & & no Brasil \\
\hline & 3= De 2 a 5 S.M. & & $5=$ Não influencia nada no que acontece \\
\hline & $4=$ De 5 a 10 S.M. & & no Brasil \\
\hline & $5=$ De 10 a 15 S.M. & Importância d & \\
\hline & $6=$ De 15 a 20 S.M. & Votaria se o vot & osse obrigatório? \\
\hline & $7=$ Mais de 20 S.M. & Codificação: & $1=\operatorname{Sim}$ \\
\hline & $8=$ Não tem renda individual & & 2 = Não \\
\hline & & Recodificação: & $0=$ Não \\
\hline & & & $1=\operatorname{Sim}$ \\
\hline
\end{tabular}

